\title{
Postcards to Myself Signed "Love, Me"
}

1. Your neighbor grew her own peanuts. They tasted like dirt. Mrs. Nichols. You sat in her dark kitchen and ate them while she stirred something on the stove. Her long braid was wrapped around her head many times. "I thought they just had salt already in them when they grew," you said.

2. Your dogs: they're lined up now in $100 \%$ walnut boxes with gold placards.

3. Walking toward something. I'm here to refill your water, maybe make coffee. The air waits full of paused wings. If you need any copies made, I'm here. I'll turn into a bed if you want me to.

4. Hi Honey. Things fine here. Have a funny story though. The other day Mom went into the garage and thought she smelled pee. We went in later and saw the pee. Later, we saw a possum in there, the one that peed. Your mother made a noose for it and we dragged it out. Then we beat it to death with oars.

5. Your house: The one from your childhood with the green shag carpet. Then it becomes whatever this is, this place where you wait. Maybe a car honks outside. Maybe it has been dark for a long time. 


\section{Waiting.}

7. The water laps around you. You look at the dog swimming beside you, her ears and glimpses of her white paws. You swim together and look into each others' eyes. Then she disappears.

You swim alone and you become the water.

8. A monkey dressed in baby clothes.

Under it in pink: "You're My Baby."

Miss you. The leaves are falling. I wish

they had fall where you are. 